\title{
Solunum Sıkıntısı ile Beraber Anemi ve Retikülosit Yüksekliği: İdiopatik Pulmoner Hemosideroz İçin Uyarıcı
}

\author{
Anemia and Reticulocyte Elevation with Respiratory Distress: \\ Warning For Idiopathic Pulmonary Hemosiderosis \\ Mina HIZAL, Sanem ERYILMAZ POLAT, Nagehan EMIRALIOĞLU, Dilber ADEMHAN TURAL, \\ Beste ÖZSEZEN, Birce SUNMAN, Ebru YALÇIN, Deniz DOĞRU, Uğur ÖZÇELIK, Nural KIPER
}

Hacettepe Üniversitesi İhsan Doğramacı Çocuk Hastanesi, Çocuk Göğüs Hastalıkları Bilim Dalı, Ankara, Türkiye

\section{öz}

Amaç: İdiopatik pulmoner hemosideroz (IPH), tekrarlayan hemoptizi, demir eksikliği anemisi ve pulmoner infiltrasyonlar ile giden nadir bir hastalıktır. Bu çalışmada başlangıçta anemi ve/veya retikülosit yüksekliği bulunan ve IPH tanısı alan hastaların özelliklerinin incelenmesi amaçlanmıştır.

Gereç ve Yöntemler: Anemi ve/veya retikülosit yüksekliği ile başvurup IPH tanısı almış ve Hacettepe Çocuk Göğüs Hastalıkları bölümünde takipte olan hastalar retrospektif olarak incelendi.

Bulgular: Çalışmaya dahil edilen 14 hastanın dokuzu (\%64.3) kızdı. Ortanca tanı yaşı 60 ay (IQR: 42)'di. Şikayetler ile tanı arasında geçen ortanca süre 12 ay (IQR:15.5)'di. Ortanca başvuru hemoglobin (Hb) düzeyleri 6.7 g/dL (IQR: 4.07), ortanca retikülosit yüzdesi 5.1 (IQR: 3.2)'di. Tanı anında hastaların sadece 5'sinde (\%35.71) hastalığın klasik triadı olan hemoptizi, demir eksikliği anemisi ve pulmoner infiltrasyon bulguları saptandı.

Oniki (\%85.7) hastada tanı anında anormal akciğer grafisi saptandı. On (71.4\%) hastaya başlangıçta pnömoni tanısı konulduğu kaydedildi. Tanı öncesinde 12 (\%85.7) hastada demir eksikliği anemisi saptanarak tedavi verildiği saptandı. Bu hastaların tümünde demir eksikliği anemisinin tedaviye dirençli seyrettiği öğrenildi. Hastaların 13'üne (\%92.9) tanı anına kadar en az bir kez kan trasfüzyonu yapılı̆̆ı saptandı.

Sonuç: IPH her zaman klasik triad șeklinde izlenmeyebilir. Demir eksikliği anemisi ile birlikte solunumsal bulguları olan ve görüntülemede pulmoner infiltrasyon bulunan hastalarda, tedavilere beklenen yanıt alınamaması veya tekrarlayan ataklar olması durumunda IPH akla gelmelidir.

Anahtar Sözcükler: Anemi, Çocukluk, İdiopatik pulmoner hemosideroz

(1D)

HIZAL M

ERYILMAZ POLAT S

EMIRALIOĞLU N

ADEMHAN TURAL D

ÖZSEZEN B

SUNMAN B

YALÇIN E

DOĞRU D

ÖZÇELIKU

KIPER $N$
Çıkar Çatışması / Conflict of Interest: Tüm yazarlar adına, ilgili yazar çıkar çatışması olmadığını belirtir.

: 0000-0002-6922-4948 0000-0003-2309-7952 0000-0002-1405-8401 $0000-0002-0334-6336$ 0000-0002-0052-8361 0000-0001-9818-8782 (0000-0003-1756-1288 :0000-0003-1756-1288

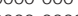
:0000-0003-1587-5216 0000-0003-1261-7393 25.08.2020 tarih ile onayı almıştır.
Yazarların katkısı / Contribution of the Authors: HIZAL M: Araștırma ve/veya makalenin hipotezini veya fikrini olușturan, Sonuçların mantıksal olarak Yorumlanması ve sonuçlandııılması, Çalıșmanın bütününün veya önemli bölümlerinin yazımında sorumluluk almak, Yazım ve dilbilgisi dışında bilimsel olarak gönderilmeden önce makaleyi gözden geçirme. ERYILMAZ POLAT S: Araştırma/çalışmanın sorumluluğunu üstlenmek, ilerlemenin seyrini denetlemek, Çalıșma için gerekli literatür taramasında sorumluluk almak. EMiRALioĞLU N: Araștırma/çalıșmanın sorumluluğunu üstlenmek, ierlemenin seyrini denetlemek, Sonuçların mantıksal olarak Yorumlanması ve sonuçlandırıması. ADEMHAN TURAL D: Hasta takibinde sorumluluk almak, ilgili biyolojik malzemelerin toplanması, veri yönetimi ve raporlama, deneylerin yürütülmesi, Çalıșma için gerekli literatür taramasında sorumluluk Imak ÖZSEZEN B: Araștırma/çalısmanın sorumluluğunu üstlenmek, ilerlemenin seyrini denetlemek, Hasta takibinde sorumluluk almak, ilgili biyolojk malzemelerin toplanması, veri yönetimi ve raporlama, deneylerin yürütülmesi, Çalıșma için gerekli literatür taramasında sorumluluk almak. SUNMAN B: Hasta takibinde sorumluluk almak, ilgili biyolojik malzemelerin toplanması, veri yönetimi ve raporlama, deneylerin yürütülmesi. YALÇıIN E: Araştıma/ çalıșmanın sorumluluğunu üstlenmek, ilerlemenin seyrini denetlemek, Hasta takibinde sorumluluk almak, ilgili biyolojik malzemelerin toplanması, çalışmanın sorumluluğunu üstlenmek, ilerlemenin seyrini denetlemek, Hasta takibinde sorumluluk almak, ilgili biyolojikk malzemelerin toplanması,
veri yönetimi ve raporlama, deneylerin yürütülmesi, Çalıșma için gerekli literatür taramasında sorumluluk almak. DOĞRU D: Arașırma/çallșmanın sorumluluğunu üstlenmek, ilerlemenin seyrini denetlemek, Hasta takibinde sorumluluk almak, ilgili biyolojik malzemelerin toplanması, veri yönetimi ve raporlama, deneylerin yürütülmesi, Çalıșma için gerekli literatür taramasında sorumluluk almak. ÖZÇELiK U: Araștırma/çalıșmanın sorumluluğunu üstlenmek, ilerlemenin seyrini denetlemek, Hasta takibinde sorumluluk almak, ilgili biyolojik malzemelerin toplanması, veri yönetimi ve raporlama, deneylerin yürütülmesi, Colşma için gerekli literatür taramasnda sorumluluk almak. KIPER N: Araștrma/çalşmanin sorumluluğunu üstlenmek, lerlemenin seyrin denetlemek, Hasta takibinde sorumluluk almak, ilgili biyolojik malzemelerin toplanmas, veri yöngth gerekli literatür taramasında sorumluluk almak.

Atıf yazım șekli / How to cite : Hızal M, Eryılmaz Polat S, Emiralioğlu N, Ademhan Tural D, Özsezen B, Sunman B ve ark. Solunum Sıkıntısı ile Beraber Anemi ve Retikülosit Yüksekliği: İdiopatik Pulmoner Hemosideroz İçin Uyarıcı. Turkish J Pediatr Dis 2021;15:
Yazışma Adresi / Correspondence Address:

Mina HIZAL

Hacettepe Üniversitesi İhsan Doğramacı Çocuk Hastanesi,

Çocuk Göğüs Hastalıkları Bilim Dalı, Ankara, Türkiye

E-posta: minahizal@outlook.com
Geliş tarihi/ Received : : 13.03.2021 Kabul tarihi / Accepted : 26.04.2021 Elektronik yayın tarihi $\quad: 24.05 .2021$ Online published

DOI: $10.12956 /$ tchd.895409 


\section{ABSTRACT}

Objective: Idiopathic pulmonary hemosiderosis (IPH) is a rare disease with recurrent hemoptysis, iron deficiency anemia, and pulmonary infiltrates. We aimed to examine the characteristics of patients who had anemia and/or elevation of reticulocyte and were diagnosed with $\mathrm{IPH}$.

Material and Methods: 14 patients with a diagnosis of idiopathic pulmonary hemosiderosis who had anemia and/or elevation of reticulocyte at initial presentation were retrospectively analyzed.

Results: A total of 14 children were included in the study. Nine (64.3\%) were female. The median age at the diagnosis was 60 months (IQR: 42). The median time from onset to diagnosis was 12 months (IQR: 15.5). The median hemoglobin levels were 6.7 g/dL (IQR:4.07). At the time of initial diagnosis, only $5(35.71 \%)$ patients had a classical triad of hemoptysis, iron deficiency anemia, and pulmonary infiltration. Abnormal chest X-ray was detected in $12(85.7 \%)$ of patients at the time of diagnosis. Ten $(71.4 \%)$ patients were diagnosed with pneumonia at the initial presentation. Iron deficiency anemia was detected in 12 (85.7\%) patients before diagnosis and all were resistant to treatment. Thirteen (92.9\%) patients had a history of blood transfusion at least once before diagnosis.

Conclusion: IPH may not always present with the classical triad. In patients with respiratory findings and pulmonary infiltration with iron deficiency anemia, IPH should be considered in unresponsive patients to treatments or recurrent attacks.

Key Words: Anemia, Children, Idiopathic pulmonary hemosiderosis

\section{GiRiş}

Idiopatik pulmoner hemosideroz (iPH), tekrarlayan hemoptizi, demir eksikliği anemisi ve pulmoner infiltrasyonlar ile giden ve çocuklarda diffüz alveolar kanamaya neden olan oldukça nadir hastalıklardan biridir $(1,2)$. Illk olarak 1864 yllında Virchow tarafından tanımlanmıştır (3).

Hastalığın altta yatan mekanizması henüz aydınlatılamamıştır. Pulmoner kapiller bazal membranında hasara yol açabilecek birçok olası tetikleyici teori üzerinde durulmaktadır. Allerjik, çevresel, genetik ve otoimmün tetiklenmeler en çok kabul gören olası nedenler arasındadır $(2,4)$. Sıklıkla çocukluk döneminde izlenmektedir $(5,6)$.

Pulmoner kanamanın altta yatan nedeni detaylı araştırmalar ile belirlenemediği durumlarda "idiopatik pulmoner hemosiderozis" terimi kullanımaktadır $(4,7)$. Hastalık genelde relapslar ile seyretmektedir (7). Kanama ataklarından sonra eritrositler alveolar makrofajlar tarafından fagosite edilir, demir hemosiderine dönüşür ve bunun sonucunda hemosiderin akciğerlerde fibrozisi tetikler $(7,8)$.

Hastalığın tanısı uyumlu klinik bulgular ile birlikte anemi ve karakteristik radyolojik görünümü olan hastalarda düşünülür ve bronkoalveolar lavaj, açlık mide sıvısı veya balgam örneği incelemelerinde hemosiderin yüklü makrofajların tespit edilmesi ile doğrulanır (7). Çok az sayıda hastanın tanısı için akciğer biyopsisi gerekmektedir (9). Nadir izlenen bir hastalık olması nedeni ile kolayllkla atlanabilir ve hastalar uzun süre boyunca farklı tanılar ile takip edilebilirler (7).

Bu çalışmada anemi ve/veya retikülosit yüksekliği ve solunumsal bulgular nedeni ile değerlendirilen ve IPH tanısı alan hastaların özelliklerinin incelenmesi amaçlanmıştır. Böylece hastaların demografik, klinik, laboratuvar ve radyolojik özelliklerinin belirlenmesi hedeflenmektedir.

\section{GEREÇ ve YÖNTEMLER}

Çalışmamıza 2000-2019 yılları arasında anemi ve/veya retikülosit yüksekliği ile başvurup IPH tanısı almış ve Hacettepe Çocuk Göğüs Hastalıkları bölümünde takipte olan hastalar dahil edilmiştir. Hacettepe Üniversitesi Girişimsel Olmayan Klinik Araştırmalar Etik Kurulu'dan GO20-297 ve 25.08.2020 tarih ile onayı almıştır. Hastaların dosya kayıtları retrospektif olarak incelenerek cinsiyet, tanı yaşı, tanıda gecikme süresi, başlangıç semptomları, sigara maruziyeti, akrabalık varlığı, yaşadıkları bölge, çevresel maruziyetler, hastaneye yatış durumları, transfüzyon intiyaçları, hemoglobin düzeyleri, retikülosit düzeyleri, MCV düzeyi, lökosit sayısı, akut faz yüksekliği, tanı gecikme süreleri, ilk tanıları, akciğer grafisi bulguları (çocuk göğüs hastalıkları uzmanı tarafından değerlendirildi), akciğer bilgisayarlı tomografi özellikleri, açlık mide sıvısı ve/ veya bronkoalveolar lavaj örneğindeki hemosiderin yüklü makrofaj varlığı, ilk basamakta aldıkları tedaviler kaydedilmiştir.

Hastalığın tanısı solunumsal semptomların varı̆̆ı, demir eksikliği anemisi ve radyolojik olarak pulmoner infiltrasyon bulunan hastalarda bronkoalveolar lavaj ve/veya açlık mide sIvı ve/ veya akciğer doku örneğinde hemosiderin yüklü makrofaj tespit edilmesi ile konuldu. Kanama bozuklukları ve kanamaya yatkınlık yaratacak diğer hematolojik hastalıklar, bronşektazi, pulmoner tüberküloz, pulmoner kanamaya neden olabilecek kardiyovasküler hastalıklar, hava yollarında yabancı cisim varlığı, vasküler malformasyonlar, vaskülitik hastalıklar gibi hemosiderozisin ikincil nedenlerini taşıyan hastalar çalışmadan çıkarıldı. Araştırmanın tanımlayıcı istatistikleri sayı, yüzde, ortanca ve çeyreklikler arası değişim (interquartile range; IQR) ile gösterildi. İstatistiksel analiz SPSS 23 paket programında değerlendirildi.

\section{BULGULAR}

Anemi ve/veya retikülosit yüksekiğinin eşlik ettiği solunumsal bulgular nedeni ile araştırlan ve izlemde İPH tanısı almış ve 
Tablo I: Hastaların demografik özellikleri.

\begin{tabular}{l|c}
\multicolumn{1}{c|}{ Değişkenler } & Hasta sayısı (\%) \\
\hline Tanı yaşı (ay) $^{*}$ & $60(42)$ \\
\hline Tanıda gecikme süresi (ay) $^{*}$ & $12(15.5)$ \\
Kadın $^{\dagger}$ & $9(64.3)$ \\
Malnütrisyon varlığı $^{\dagger}$ & $3(21.4)$ \\
Sigara öyküsü $^{\dagger}$ & $4(28.6)$ \\
\hline Akrabalık varlığı & \\
\hline
\end{tabular}

*Ortanca ve çeyreklikler arası değişim (interquartile range; IQR) ile gösterildi, ${ }^{\dagger} n(\%)$

Hacettepe Üniversitesi Çocuk Göğüs Hastalıkları bölümünde takipte olan 14 hasta çalışmaya dahil edildi. Hastaların dokuzu (\%64.3) kızdı. Hastaların ortanca tanı yaşı 60 ay (IQR: 42)'di. Şikayetler ile tanı arasında geçen ortanca süre 12 ay (IQR:15.5)'di. Altı (\%42.9) hastada birinci veya ikinci derece akrabalık vardı. Tanı anında üç (\%21.4) hastada malnütrisyon tespit edildi. Dört (\%28.6) hastada pasif sigara maruziyeti vardı. Tüm hastalar kentte yaşamaktaydı. Hiçbir hastada sigara dışında şüpheli çevresel maruziyet tespit edilmedi. Hastaların demografik özellikleri tablo l'de özetlenmiştir.

Hastaların ortanca geliş hemoglobin $(\mathrm{Hb})$ düzeyleri $6.7 \mathrm{~g} / \mathrm{dL}$ (IQR: 4.07) iken, ortanca retikülosit yüzdesi 5,1 (IQR: 3.2) olarak saptandı. Ortanca MCV değeri 69 fl (IQR: 7.6) olarak tespit edildi. Ortanca lökosit değeri 15.600/mm³ (IQR: 12.900) saptandı. Beş (\%35.7) hastada tanı anında akut faz reaktanlarında yükseklik mevcuttu (C- reaktif protein ve/veya sedimantasyon hızı). Tanı anında hastaların sadece 5'sinde (\%35.71) hastalığın klasik triadı olan hemoptizi, demir eksikliği anemisi ve pulmoner infiltrasyon bulguları saptandı. Tanı anında hastaların beşinde (\%35.71) hemoptizi, altısında (\%42.9) ateş, 11'inde öksürük (\%78.6), 10'unda nefes darlığı (\%71.4), birinde (\%7.14) göğüs ağrısı şikâyeti vardı (Tablo II). Tanı anında hastaların yedisinde (\%50) hipoksi vardı. Bir hastanın tanı anında entübasyon ile mekanik ventilasyon desteğine, bir hastanın ise non-invazif solunum desteğine intiyacı oldu. Fizik muayenede 12 hastada solukluk (\%85.7) saptanırken üç hastada (\%21.4) ral saptandı.

Oniki (\%85.7) hastada tanı anında anormal akciğer grafisi saptandı. Onbir (\%78.6) hastanın akciğer grafisinde değişen yaygınlıkta buzlu cam görünümü mevcuttu. Hastaların beşinde (\%35.7) akciğer grafisinde alveolar infiltrasyon paterni saptandı. Tüm hastaların akciğer tomografisi mevcuttu ve dokuzunda (\%64.3) buzlu cam görünümü, yedisinde (\%50) konsolidasyon görünümü ve beşinde (\%35.7) diffüz nodüler görünüm, dördünde (\%28.6) fokal nodüler görünüm saptandı (şekil 1 ve şekil 2 IPH tanısı olan iki hastaya aittir). Sekiz hastanın açlık mide sıvı örneğinde hemosiderin yüklü makrofaj saptanırken, 10 hastanın bronkoalveolar lavaj örneğinde hemosiderin yüklü makrofaj tespit edildi. Üç hastaya akciğer biyopsisi yapıldı ancak vaskülitik tutulum izlenmedi. Anti-glomerüler bazal membran (anti-GBM) kayıtlarına ulaşlabilen on hastanın hepsinde sonuç negatifti.
Tablo II: Başlangıç aşamasında izlenen klinik bulgular.

\begin{tabular}{l|c|}
\hline \multicolumn{1}{|c|}{ Klinik bulgular } & Hasta sayısı (\%) \\
\hline Hemoptizi & $5(35.71)$ \\
\hline Öksürük & $11(78.6)$ \\
\hline Nefes darlığı & $10(71.4)$ \\
\hline Ateş & $6(42.9)$ \\
\hline $\begin{array}{l}\text { Göğüs ağrısı } \\
\text { Hemoptizi, anemi ve pulmoner } \\
\text { infiltrasyon triadı }\end{array}$ & $1(7.14)$ \\
\hline
\end{tabular}

On (\%71.4) hastaya ilk şikayetleri olduğunda pnömoni tanısı konulduğu ve antibiyotik tedavisi başlandığı saptandı. Tanı öncesinde 12 (\%85.7) hastada demir eksikliği anemisi saptanarak tedavi verildiği saptandı. Bu hastaların tümünde demir eksikliği anemisinin tedaviye dirençli seyrettiği saptandı. Hastaların 13'üne (\%92.9) tanı anına kadar en az bir kez kan trasfüzyonu yapıldığı saptandı. Tüm hastaların tanı anına kadar en az bir kere hastanede yatış öyküsü mevcuttu. Tanı sonrasında tüm hastalara ilk basamak tedavi olarak hastalığın şiddetine göre farklı etkinliklerde steroid tedavisi başlandı.

\section{TARTIŞMA}

İdiopatik pulmoner hemosiderozis çocukluk döneminde oldukça ender görülmektedir. İnterstisiyel akciğer hastalıklarının bir alt grubu olarak sınıflanan bu hastalı̆ıın altında yatan patoloji tam olarak aydınlatılamamışıı $(10,11)$. Hastalı̆ıı gerçek insidansı bilinmemekle birlikte çocukluk döneminde milyonda 0.241.23 olduğu düşünülmektedir (5). Hastalığın patofizyolojisini tekrarlayıcı alveol içi kanamalar oluşturmaktadır ve bu kanamalara bağlı akciğerde fibrin yapımı tetiklenebilmektedir. Ayrıca tekrarlayan kanamalar demir eksikliği anemisine neden olmaktadır (12).

Hastalığın tanısı solunumsal semptomların varlığı, demir eksikliği anemisi ve radyolojik olarak pulmoner infiltrasyon bulunan hastalarda bronkoalveolar lavaj ve/veya açllk mide sıvı ve/ veya akciğer doku örneğinde hemosiderin yüklü makrofaj tespit edilmesi ile konulmaktadır. Akciğer biyopsisi sınırlı sayıda hastada gerekmektedir. Hastalarda öncelikle pulmoner hemorojinin olası diğer nedenleri arasında bulunan solunum yolları enfeksiyonlar, koagulapati, sistemik lupus eritematozus, poliangiitisli granülomatozis (Wegener granülomatozisi), antiglomerüler bazal membran hastalığı, pulmoner venookluziv hastalık ve toksinler maruziyet gibi durumların dışlanması gerekmetedir. Ayrıca çölyak hastalığı ile birliktelik olabildiği için, hastaların bu yönden taranması önerilmektedir $(1,5,13)$.

Tüm yaşlarda görülebilmekle beraber çocukluk döneminde daha sık izlenmektedir (6). Çin'de yapılan çalışmada hastaların \%80'ninde IPPH'in ilk dekatta görüldüğü bildirilmiștir (7). Tayard 


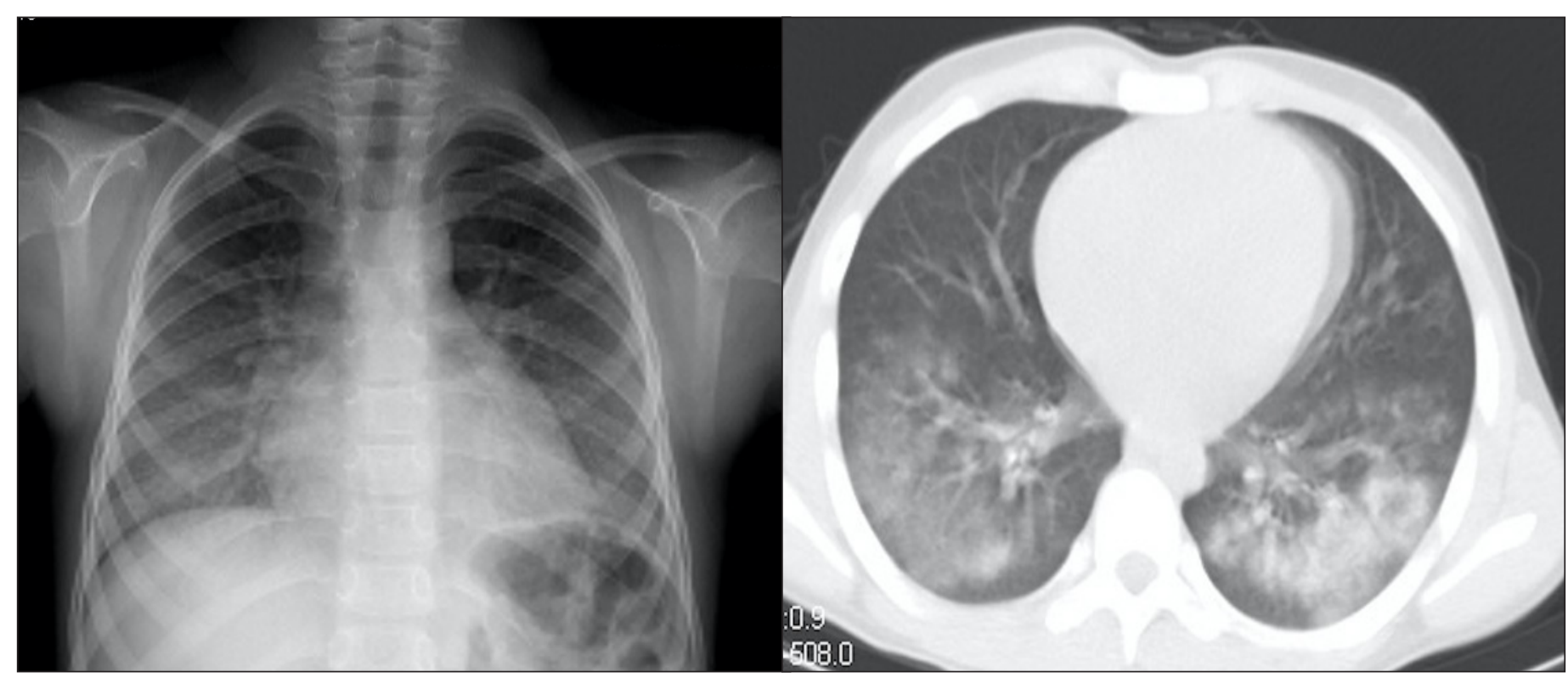

Şekil 1: Ön-arka akciğer grafisinde bilateral alveolar infiltrasyon görünümü.

ve ark. (4) yaptı̆̆ı ve Fransız kayıt sisteminden elde edilen 25 hastanın sonuçlarıı inceleyen çalışmada ortanca tanı yaşı 4,3 yaș olarak bulunmuştur. Zan ve ark. (2) 2019 yllında yayımlanan çalışmalarında ortanca tanı yaşı 6 yıl olarak bildirilmiştir. Çalışmamızda ortanca hasta tanı yaşının 60 ay olduğu görülmektedir. Literatür ve çalışmamız hastalığın genellikle hayatın ilk dekatında izlendiğini göstermektedir.

IPH'e yatkınlık oluşturan bilinen cinsiyet, ırk ve bölgesel hakimiyet bulunmamaktadır (3). Çalıșmamızda tüm hastalar kentte yașadığı ve belirgin bir bölgesel dağım ve çevresel maruziyet göstermemektedir. Hem çalışmamızda hem de Zhang ve ark. (7) yaptığı çalıșmada görüldüğü üzere cinsiyet dağıımının genellikle eșit olduğu izlenmektedir.

Hastalığın başlangıç bulgusu oldukça değişken olabilmektedir (9). Hastalığın klasik triadı olarak bilinen hemoptizi, demir eksikliği anemisi ve pulmoner infiltrasyon çalışmamızda tanı anında sadece \%357 hastada izlenmektedir. Zhang ve ark. (7) $28 \mathrm{IPH}$ hastasını değerlendirdiği çalışmada hastaların \%517'sinde hastalığın klasik triadının izlendiği belirtilmektedir ancak bu çalışmada belirtilen klasik triad bulgularının hastalığın başlangıç aşamasında mı yoksa seyri boyunca mı olduğu belirtilmemektedir. Hastalığın klasik triadı olarak bilinen bulguların başlangıç döneminde her hastada izlenmemesi ve değişken klinik bulguları olabilmesi nedeniyle tanıda gecikme veya farklı tanıların konulması durumları olabilmektedir (7).

Çalışmamızda tanı anında en sık rastlanılan pulmoner semptomların öksürük, nefes darlığı ve ateș olduğu görülmektedir. Tayard ve ark. (4) çalışmasında tanı anında en sık șikayetin öksürük ve nefes darlığı olduğu bildirilmektedir (4). Zhang ve ark. (2) 2019 yllında yaptı̆̆ı çalışmada ise başlangıç döneminde izlenen en sık bulguların öksürük, hemoptizi ve nefes darlığı olduğu
Şekil 2: Akciğer bilgisayarlı tomografide bilateral buzlu cam opasite görünümü.

görülmüștür. Hastalarda tanı anında hemoptizi olmayabilir (9). Tayard ve ark. (4) yaptığı çalıșmada tanı anında hastaların \%44'ünde hemoptizi olduğu bildirilmiștir. Le Clainche ve ark. (3) yaptığı çalıșmada hastaların \%40'ında tanı anında hemoptizi olduğu raporlanmıștır. Çalıșmamızda tanı anında sadece hastaların beşinde (\%35.7) hemoptizi görülmüştür. Bulgularımı, benzer çalışmalarda olduğu gibi hastalı̆ı̆ klasik triadı içinde yer alan hemoptizinin tanı anında önemli oranda olmayabileceğine dikkat çekmektedir.

Nedeni açıklanamayan anemi ve büyüme gelișme geriliği hastalığın bașlangıç semptomları arasında yer alabilmektedir (9). Çalıșmamızda semptomların ilk başlangıç döneminde hastaların \%85,7'sinde demir eksikliği anemisi tanısı konularak tedavi verildiği görülmektedir. Zhang ve ark. (2) yapmış olduğu çalışmada tanı anında hastaların \%93.4'ünde anemi saptandığı belirtilmektedir. Kbara ve ark. (13) yaptığı çalışmada tüm hastalarda değişen derecelerde anemi olduğu bildirilmiştir. Ayrıca Le Clainche ve ark. (3) yaptığı çalısmada 15 hastanın \%86'sında tanı anında anemi olduğu bildirilmektedir. Çalışmamız ve benzerleri demir eksikliği anemisi olan çocuklarda pulmoner infiltrasyon ve respiratuvar șikayetlerin varlığında ayırıcı tanıda IPH'in akılda bulundurulmasının önemine ișaret etmektedir $(7,13)$.

IPH'de anemi kronik kan kaybına bağı olarak ortaya çıkan hipokrom mikrositer demir eksikliği anemisi șeklindedir ancak tedaviye yanıt demir eksikliği anemisinde beklendiği kadar hızlı değildir (5). Ayrıca hastalarda retikülosit artışı uyarıcı olmalıdır. Çalışmamızda hastaların \%92.9'unda trasfüzyon ihtiyacı olduğu izlenmektedir. Le Clainche ve ark. (3) çalışmasında hastaların çoğunun ağır anemisi olduğu ve \%60'ının trasfüzyon intiyacı olduğu bildirilmektedir. Çalıșmamızın planlanma şekli nedeni ile anemisi olan IPH'li hastalar incelenmiștir. Bu nedenle trasfüzyon 
intiyacı çalışmamızda diğer çalışmalara göre daha yüksek izlenmektedir. Ancak bulgularımı özellikle standart tedavilere yanıt vermeyen, eşlik eden solunumsal bulguları olan ve nedeni açıklanamayan demir eksikliği anemisi olan hastalarda tanıda IPH'in akla gelmesi gerektiğini göstermektedir.

IPH'in hem çok nadir görülmesi hem de değişken klinik bulgularla ortaya çıkabilmesi tanıda gecikmelere neden olmaktadır (5). Çalışmamızda şikayetlerin ortaya çııışı ile tanı arasında geçen ortanca sürenin 12 aya kadar uzayabildiği görülmüştür. Fransa'dan yapılan bir çalışmada en uzun tanı gecikmesi olan hastada 16 ay gecikme olduğu bildirilmektedir (4). Zhang ve ark. (2) yaptığı çalışmada ise semptomların başlamasından tanıya kadar geçen süre ortalama 10.4 ay olarak bulunmuştur. Kabra ve ark. (13) yaptığı çalışmada ortalama tanı gecikme zamanı 30 ay olarak bildirilmiştir. Çalışmamı ve literatürdeki örnekler hastalarda tanı gecikmesinin sıklıkla izlendiğini göstermektedir.

Çalışmamızda hastaların sadece \%21.4'ünde fizik muayenede ral tespit edilmiştir. Çin'de yapılan bir çalışmada benzer şekilde sadece hastaların \%15.8'inde krepitan ral olduğu görülmektedir (2). Literatüre benzer şekilde çalışmamı da muayenede solunum sisteminde dinleme bulgusunun olmayabileceğini göstermektedir.

IPH'deakciğergörüntülemesindeçeșitlibulgulargörülebilmektedir. Bilateral alveolar infiltrasyon, retikülonodüler değișiklikler, buzlu cam görünümü ve interstisyel patern bunlardan bazılarıdır. Bulgular özellikle diffüz enfeksiyon ve viral pnömoniler ile karışabilmektedir. Bazı hastalarda yamasa gezici alveolar infiltrasyon görülebilmektedir. $(1,4,7)$. Çalışmamızda hastaların \%85.7'sinde tanı anında akciğer grafisinde anormal görünüm saptanmıştır. Zhang ve ark. (2) çalışmasında da tüm hastalarda akciğer grafileri ve/veya bilgisayarlı tomografilerde anormal görüntüleme bulgusu olduğu bildirilmektedir. Le Clainche ve ark. (3) çalışmasında \%93.3'ünde tanı anında akciğer grafisinde anormallik izlenmiştir. Hastaların çoğunda akciğer grafisinde anormal görünüm olması, çalışmamızda da belirtildiği üzere bu hastaların sıklıkla pnömoni tanı ve tedavisi almasına katkıda bulunmuş olabilir.

IPH bulgularının çocukluk döneminde sık izlenen pnömoni ve astım gibi solunum yolu hastalıklarına benzemesi nedeni ile tanı genellikle gecikmektedir (9). On (\%71.4) hastaya ilk șikayetleri olduğunda pnömoni tanısı konulmuştur ve antibiyotik tedavisi başlanmıştır. Zhang ve ark.(2) yapmış olduğu çalışmada da hastaların \%73.8'ine ilk aşamada yanlış tanı konulduğu bildirilmektedir. Bahsedilen çalışmada en sık yanlış tanı nedeni demir eksikliği anemisi ve pnömoni olarak bildirilmiştir. IPH'in hem klinik bulgularının çeşitli olması hem de hastalığın az görülmesine bağı olarak farkındalığın düşük olması başlangıçta yüksek oranda yanlış tanı konulmasına sebebiyet veriyor olabilir. Bu nedenle tanı için hastalığın akla gelmesi ve yüksek şüphe varığı çok önemlidir.
Çalışmamızda tüm hastaların tanı alana kadar en az bir kez hastanede yatış gerektiren klinikleri olmuştur. Kabra ve ark. (13) Hindistan'da yaptıkları ve 26 hastanın retrospektif olarak incelendiği araştırmada, çalışmamıza benzer şekilde tüm hastaların hastane yatışına intiyacı olduğu ve hasta bașına ortalama 3.5 yatış olduğu bildirilmiştir. Ayrıca akut ataklar sırasında respiratuvar yetmezliğe bağlı solunum desteği intiyacı olabilmektedir (9). Çalışmamızda iki hastanın tanı öncesinde akut solunum yetmezliğine bağlı solunum desteği intiyacı olduğu görülmektedir. Bu bulgular klinik seyri değişken bir hastalık olan IPH'in akut dönemde ağır solunum yetmezliği ile ortaya çıkabileceğini göstermektedir.

Oldukça nadir görülen bir hastalık olması nedeniyle tedavisiyle ilgili randomize kontrollü çalışma bulunmamaktadır. Akut dönemde hastaların şikayetlerine yönelik destek tedavi verilmesi önerilmektedir (3). Çalışmamızda hastaların sıkıkla trasfüzyon desteğine intiyaçlarının olduğu, invaziv veya non-invaziv solunum desteği intiyaçları olabildiği görülmektedir. Steroid tedavide ilk tercih edilen ajandır (9). Le Clainche ve ark. (3) çalışmasında hastaların \%93'ünün uzun dönemde steroid tedavisi aldığı bildirilmektedir. Çalışmamızda tüm hastalara ilk basamakta steroid tedavisi verildiği izlenmektedir. Her ne kadar steroid tedavisinin etkinliğini çocuklarda kanıtlayan kontrollü çalışmalar olmasa da çalısmamı ve literatür örneklerinde görüldüğü üzere kortikosteroid tedavisi halen ilk tercih edilen tedavi modalitesi olmaya devam etmektedir.

Bu retrospektif çalışmada anemi ve/veya retikülosit yüksekliği ve solunum sistemi șikayetleri ile başvuran ve IPH tanısı alan hastaların özellikleri incelenmiştir. Çalışmamızda görüldüğü üzere hastalığın klinik bulguları her zaman bilinen klasik triad şeklinde olmayabilir. Hastalar solunum sıkıntısı, öksürük ve ateş gibi çeșitli bulgularla karşımıza gelebilmektedir. Klinik seyirde değişkenlik olması hastaların tanısında gecikmelere neden olmaktadır. Bu nedenle demir eksikliği anemisi ile birlikte solunum sistemi semptomları olan ve radyolojik görüntülemede pulmoner infiltrasyon tespit edilen hastalarda, standart tedavilere beklenen yanit alınamaması durumunda ve /veya tekrarlayan benzer şikayetlerinin olması halinde hekimlerin IPH tanısını gecikmeden akla getirmesi önem taşımaktadır.

\section{KAYNAKLAR}

1. de Silva C, Mukherjee A, Jat KR, Lodha R, Kabra SK. Pulmonary Hemorrhage in Children: Etiology, Clinical Profile and Outcome. Indian J Pediatr 2019;86:7-11.

2. Zhang Y, Luo F, Wang N, Song Y, Tao Y. Clinical characteristics and prognosis of idiopathic pulmonary hemosiderosis in pediatric patients. J Int Med Res 2019;47:293-302.

3. Le Clainche L, Le Bourgeois M, Fauroux B, Fauroux B, Forenza N, Dommergues JP, et al. Long-term outcome of idiopathic pulmonary hemosiderosis in children. Medicine (Baltimore) 2000;79:318-26. 
4. Taytard J, Nathan N, de Blic J, Fayon M, Epaud R, Deschildre A, et al. New insights into pediatric idiopathic pulmonary hemosiderosis: the French RespiRare (R) cohort. Orphanet J Rare Dis 2013;8:161.

5. Bakalli I, Kota L, Sala D,Celaj E,Kola E, Lluka R, et al. Idiopathic pulmonary hemosiderosis - a diagnostic challenge. Ital J Pediatr 2014;40:35.

6. Kiper N, Gocmen A, Ozcelik U, Dilber E, Anadol D. Long-term clinical course of patients with idiopathic pulmonary hemosiderosis (1979-1994): prolonged survival with low-dose corticosteroid therapy. Pediatr Pulmonol 1999;27:180-4.

7. Zhang X, Wang L, Lu A, Zhang M. Clinical study of 28 cases of paediatric idiopathic pulmonary haemosiderosis. J Trop Pediatr 2010;56:386-90.

8. Castellazzi L, Patria MF, Frati G, Esposito AA, Esposito S. Idiopathic pulmonary haemosiderosis in paediatric patients: how to make an early diagnosis. Ital J Pediatr 2016;42:86.
9. Ahmed M, Raj D, Kumar A, Kumar A. Anaemia and respiratory failure in a child: can it be idiopathic pulmonary haemosiderosis? BMJ Case Rep 2017;2017.

10. Blanco A, Solis P, Gomez S, Valbuena C, Telleria JJ. Antineutrophil cytoplasmic antibodies (ANCA) in idiopathic pulmonary hemosiderosis. Pediatr Allergy Immunol 1994;5:235-9.

11. Kurland G, Deterding RR, Hagood JS, Hagood JS, Young LR, Brody AS, et al. An official American Thoracic Society clinical practice guideline: classification, evaluation, and management of childhood interstitial lung disease in infancy. Am J Respir Crit Care Med 2013;188:376-94.

12. Poggi V, Lo Vecchio A, Menna F, Menna G. Idiopathic pulmonary hemosiderosis: a rare cause of iron-deficiency anemia in childhood. J Pediatr Hematol Oncol 2011;33:e160-2.

13. Kabra SK, Bhargava S, Lodha R, Satyavani A, Walia M. Idiopathic pulmonary hemosiderosis: clinical profile and follow up of 26 children. Indian Pediatr 2007;44:333-8. 